\title{
THE EFFECT OF COOPERATIVE LEARNING MODEL OF NUMBER HEAD TOGETHER (NHT) TYPE ASSISTED ANIMATION ON STUDENT'S LEARNING OUTCOMES OF X CLASS SMA 2 LINTONGNIHUTA A.Y. 2014/2015
}

\author{
Nancy Alretni Mendrofa dan Jonny H. Panggabean \\ Physic Education Faculity Mathematic and Natural Science \\ State University of Medan \\ mendrofanancy@yahoo.co.id
}

\begin{abstract}
Aims of study to determine the effect of cooperative learning model of NHT type to learning outcomes of students in subject matter optical geometry in high school N 2 Lintongnihuta A.Y. 2014/2015.Kind of this research is quasi experimental. The population in this research were all students of class $\mathrm{X}$ Semester II SMA N 2 Lintongnihuta which consists of two classes. Sampling was done by purposive research by using two existing classes, namely class $\mathrm{X}$ Mia 2 were 26students as experimental class and the class X Mia 1 amounted to 30 students as the control class. The instrument used is a cognitive test in the form of multiple choice question number 20 and observation sheet of student's activity. Experimental class was given treatment by cooperative learning model of NHT type and grade control with conventional learning.

Before being given different treatment performed pretest, which is the average value of the experimental class pretest 48.65 with a standard deviation 11.45 and the average value of the control class pretest 48.67 with a standard deviation 14.07. Second class pretest data testing showed that both classes of data were normally distributed and homogeneous. The test results obtained pretest $t_{\text {count }}<t_{\text {table }}(0.0057<2,14)$ then $\mathrm{H}_{0}$ is received, it means the ability of students' initial experimental class and control class alike. Then given treatment that is experimental class with cooperative learning model of NHT type and grade control with conventional learning models. During thelearning processinthe experimental classlearning activities of studentsincreased, the meetingI59.79\%, $72.07 \%$ meetingIIandIIImeeting of $75.30 \%$.After the study was completed, given postest with an average 66.53 for experimental class with a standard deviation 11.64 and 48.66 with the control class standard deviation 14.07. On testing normality and homogeneity of data obtained postest that both classes of data were normally distributed and homogeneous. The data processing postest obtained that $\mathrm{t}_{\text {count }}=5.1$ and $\mathrm{t}_{\text {table }}=2.14$, so that $\mathrm{t}$ count $>\mathrm{t}$ table $(5.1>2.14)$ then $\mathrm{H}_{\mathrm{a}}$ received means there is influence of cooperative learning model of NHT type to students learning outcomes in optic geometry material to X class SMA N 2 Lintongnihuta A.Y. 2014/2015.
\end{abstract}

Keywords: Cooperative learning model of NHT type, animation, learning outcome, activity. 


\section{BACKGROUND}

Development

of

scienceand technology todayrelated to progress ofphysical science.Asone of sciencethat studyabout natural phenomenathatoccurin daily lives, both theoretically andmathematically.

Based on experience during PPLT at SMAN 2 Lintongnihuta also through interviews with teachers, students difficult to understand the subject matter because student tend to work individually so the less students avers to ask to able student. Learning still use teacher center cause less socialiszation betweenstudents, interaction is still less, students tend to work individually. Lack of opportunity for weak students to interact or ask the students are able to more easily understand the explanation from teacher.

Various effort are made to increase student's learning outcomes. One of them is using innovative learning. Cooperative learning model is an instructional model that directs students to work in groups and discuss. Students more easily understand the lesson because it can directly exchange ideas with other students.

There are many quite different form of cooperative learning model, but all of them involve having students work in group or teams to help one other learn academic material. Cooperative learning usually supplements the teacher's instruction by giving students an opportunity to discuss information or practice skill originally presented by the teacher; sometimes cooperative model required students to find or discover information on their own.

Onetype ofcooperative learning model thatcanbe usedis theNumber
Head Together(NHT). Where students are directly involved repeat material covered in the lesson. Students are giventhe opportunity to exchange idea sand consider the most appropriate answer or assignment of teachers and also encourage students to improve their spirit of cooperation.

NHT has applied by some researcher or student university as before research. Before research show if average mark in experiment class increase from 24,05 before used Cooperative learning model of NHT type, to be 64,76 after use Cooperative learning model of NHT type. And according Intan (2014)the mark of student in experiment class increase about 24.08 used Cooperative learning model of NHT type, to be 78,54 after use Cooperative learning model of NHT type.

Based on the result of research by previous research, so researcher felt compelled to conduct this research in an effort toovercome theweaknessesin previous research. Researcherswill try toallocatetimeas possible and using animation, as a learning tool to help students in capturing explanations, ideas, and easier to recall the lessons that can maximize the learning process.

Based of above background so writter interest to research with title: "The Effect Of Cooperative Learning Model Of Number Head Together (NHT) Type Assisted Animation On Student's Learning Outcomes of $\mathrm{X}$ Class SMA 2 Lintongnihuta A.Y. 2014/2015".

\section{RESEARCH METHOD}

Type of research is a quasi experiment. Quasi experiment is a research to know have or not the effect of the model of the student's 
learning outcomes.

Population in this research is all of grade X SMA Negeri 2 Lintongnihuta. Because election in this school only science mayor.Research sample are obtained by technique purposive research.Sample is grade X SMA N 2 Lintongnihuta.

Research instrument in this research are 20 multiple choise test where have a,b,c,d, and e chosen and observation table of student's activity - Before the instrument give to the sample class, the first question tested validated.

Hypothesis test conducted by comparing the average scores achieved learning outcomes either the experimental group or the control group. The data obtained are tabulated then searched the average. Prior to analyzing the data, it must first be determined score of each sample group last performed data processing with the following steps:

a) Calculate the average value and standard deviation

b) Test of normality by using test Lilliefors

c) Test homogeneity using two variance equality test

Test for normality and homogeneity test is intended as a prerequisite to test the hypothesis if the population is normally distributed and homogeneous.

d) The hypothesis testing using t test

Two hypothesis test is used to determine the similarity of initial ability of students in both groups of samples and test hypothesis one hand is used to determine the effect of a treatment that use traditional problem-based learning model animation on student learning outcomes.

\section{RESULT AND DISCUSSION \\ Research Result}

Result of this research is average of experiment class's pretest namely 48.6 and average of control class pretest is 48.6 , show in table 1 .

Tabel 1. Data pretest of experiment and control class

\begin{tabular}{|c|c|c|c|c|c|c|c|c|c|}
\hline \multirow{2}{*}{ No. } & \multirow{2}{*}{ Value } & \multicolumn{4}{|c|}{ Experiment Class } & \multicolumn{4}{|c|}{ Control Class } \\
\hline & & $f$ & & $\boldsymbol{S}^{2}$ & $S$ & $f$ & & $S^{2}$ & $S$ \\
\hline 1. & 25 & 0 & \multirow{10}{*}{48.6} & \multirow{10}{*}{131.1} & \multirow{10}{*}{11.4} & 2 & \multirow{10}{*}{48.6} & \multirow{10}{*}{181.6} & \multirow{10}{*}{13.4} \\
\hline 2. & 30 & 2 & & & & 3 & & & \\
\hline 3. & 35 & 4 & & & & 2 & & & \\
\hline 4. & 40 & 2 & & & & 4 & & & \\
\hline 5. & 45 & 3 & & & & 3 & & & \\
\hline 6. & 50 & 5 & & & & 3 & & & \\
\hline 7 & 55 & 5 & & & & 4 & & & \\
\hline 8 & 60 & 2 & & & & 4 & & & \\
\hline 9 & 65 & 1 & & & & 3 & & & \\
\hline 10 & 70 & 2 & & & & 2 & & & \\
\hline
\end{tabular}

Normality test aimed to see whether the sample normal distribution or not. Pretest data normality test experimental class and control class using test Lilliefors. Results of the pretest data normality test both classes are shown in Table 2

Table 2 Normality of Pretest Test Data

\begin{tabular}{|c|c|c|c|c|}
\hline No. & Data pretest & $\mathrm{L}_{\text {count }}$ & $\mathrm{L}_{\text {table }}$ & Conclusion \\
\hline 1 & $\begin{array}{c}\text { Experiment } \\
\text { Class }\end{array}$ & .1137 & 0.161 & Normal \\
\hline 2 & Control Class & .1557 & 0.161 & Normal \\
\hline
\end{tabular}

Table2 shows that the experimental class $\mathrm{L}$ count $<\mathrm{L}$ table $(0.1137<0.161)$ as well as the control class where $\mathrm{L}$ count $<\mathrm{L}$ table $(0.1557$ $<0.161$ ) with $a=0.05$. Based on the results obtained it can be concluded that both classes of data are normally distributed.

Observations made by two 
observers / observer consisting of university student. The teaching and learning activities performed during three meetings with the activity observed by the observer. The observed activity is peresentase involvement of the student, and then classified on both criteria, very good, good, and enough as follows in Table 3:

Table 3: Student Activity of Experiment Class

\begin{tabular}{|c|c|c|c|c|}
\hline \multirow{2}{*}{ No. } & \multicolumn{4}{|c|}{ Note } \\
\hline \multirow{2}{*}{1} & $\begin{array}{c}\text { Activity } \\
\text { average } \\
\text { value }\end{array}$ & $\begin{array}{c}1 \text { st } \\
\text { meeting }\end{array}$ & $\begin{array}{c}2^{\text {nd }} \\
\text { meeting }\end{array}$ & $\begin{array}{c}\text { 3rd } \\
\text { meeting }\end{array}$ \\
\hline
\end{tabular}

Based on the pre-test was done in second grade samples, grade can be determined experimentally with the control class. Experimental class is a class X IPA-2 are given the treatment by applying a model of cooperative learning NHT type and grade control is a class X IPA-1 is taught using conventional teaching. After completion of the learning process, conducted posttest to determine the ability of the student's final.

$$
\text { Posttest results }
$$

of

experimental class and control class were tested in common with one hand using hypothesis testing using $t$ test, provided that the data should be normally distributed and homogeneous. Here is an explanation of the test for normality and homogeneity test in experimental class and control class.

Normality test aimed to see whether the sample normal distribution or not. Posttest data normality test experimental class and control class using test Lilliefors. The results of the second post-test data normality test class are shown in Table 4.
Table 4: Normality Test Data posttest

\begin{tabular}{|c|c|c|c|c|}
\hline No. & Data posttest & $\mathrm{L}_{\text {count }}$ & $\mathrm{L}_{\text {table }}$ & Conclusion \\
\cline { 1 - 4 } 1 & $\begin{array}{c}\text { Experiment } \\
\text { Class }\end{array}$ & 0.1081 & 0.161 & \multirow{2}{*}{ Normal } \\
\cline { 1 - 4 } 2 & Control Class & 0.0957 & 0.161 & \\
\hline
\end{tabular}

Table 5 shows that the experimental class $\mathrm{L}$ count $<\mathrm{L}$ table $(0.1081<0.161)$ as well as the control class where $\mathrm{L}$ count $<\mathrm{L}$ table $(0.0957$ $<0.161$ ) with $\alpha=0.05$. Based on the results obtained it can be concluded that both classes of data are normally distributed.

\section{Discussion}

Value of the average pretest students in the control class is 48.65 and the average post-test score of 58.33 , while in the experimental class average value pretest 48.66 and the average value posttest 66.53. The results showed that there was a significant effect on student learning outcomes using cooperative learning model of NHT type of the material Optic Geometry in Class X Science Semester 2 SMAN 2 Lintongnihuta. While the activities of students in the experimental class of each meeting is also a good change where the average activity of each meeting students from the first to the third meeting in a row is $59.73,72.02,75.30$.

Results of student learning in the classroom experiments that use cooperative learning models of NHT type shows better results than the class that uses conventional learning because students be happy to follow the lesson. Students are happy because they are given a greater opportunity to interact with her to discuss the matter and do the exercise, also students through quizzes Number Head Together (NHT) are encouraged to work in 
teams to prepare a better answer to get more satisfactory results. Pleasure making students become more active. Students active in seeking information, to understand the material learned through textbooks and internet. Students become compact with the group's friends and cooperate in doing exercises that are worksheet. Students give each other feedback to one another.

According to researchers, one alternative to improve learning outcomes and student activity is to use cooperative learning model of NHT type of learning. The study, conducted by researchers by applying cooperative learning model of NHT type of learning is very interesting students, so the students were very enthusiastic learning. Application of cooperative learning models of NHT type make students more compact and help each other. Students who can not afford to ask the more affluent students in such materials.

Stage a preparatory step teachers prepare lesson plans to make Scenario Learning , Student Worksheet (LKS) in accordance with the cooperative learning model NHT. Step group formation, in the formation of groups adapted to the type of cooperative learning model of NHT. Teachers divide the students into groups consisting of 3-5 students. Teacher gives a number to each student in the group and the name of a different group. A group formed by a mixture which in terms of social background, race, ethnicity, gender and learning ability. Moreover, in the formation of the group used the value of the initial test (pre-test) as the basis for determining each group. Step each group must have textbooks or guidebooks, in the formation of groups, each group must have textbooks or guidebooks to facilitate students in completing worksheets or problems assigned by the teacher. Step discussions problem, in group work, teachers distribute worksheets to each student as a material to be studied. In group work each student to think together to describe and make sure that everyone knows the answer to that question has existed in worksheets or questions that have been given by the teacher. Questions can be varied, from the specific to the general. Step call the number of members or the provision of answers, in this stage, the teacher calls the number and the students from each group with the same number of raised hands and prepare answers to the students in the class. Step conclusions, teachers with students concluded the final answer of all questions relating to the material presented.

Previous researchers, Marbun, (2013)., Concluded that the experimental class learning outcomes in the realm of knowledge with an average of 79.5 postest who use cooperative learning models of NHT type was higher than the control class learning outcomes that do not use a model of cooperative learning NHT type with an average value of 65.2. The use of cooperative learning model of NHT type of the experimental class have a significant influence on student learning outcomes can't be separated from the activities that followed the students during the learning process.

The research results prove that the implementation of cooperative learning model of NHT type can develop students' learning activities in the form of activities: 1) making observations; 2) ask; 3) conduct an 
investigation or trial; 4) reasoning; and 5) relationships with others in an attempt to obtain information or data (communicate).

Cooperative learning is a model of NHT type requires students to work together in improving learning outcomes. Based on the research conducted, the student is able to cooperate in studying and doing exercises on worksheets students. This increase impact on student learning outcomes individually.

The use of cooperative learning models of NHT type can improve learning outcomes and student activities, but during the course there are still obstacles faced is when guiding the group in directing the group, using quite a long time because it has not been working on the project students in learning. Shyness and hesitancy in making conclusions are still embedded in the students, so that students have difficulty in making the conclusion of the study group.

Constraints faced by researchers is the distribution and allocation of time spent in each meeting so that maximum. Researchers require a long time to direct the discussions and working groups in the exercise due to lack of proficient researchers in directing the group because unfamiliar. In addressing this problem researchers have recourse to direct the observer to participate in study group.

\section{CONCLUSIONS AND SUGGESTIONS}

Conclusions of this study are based on the finding of the research data, systematic grain done by paying attention to the research that has been formulated. The conclusions obtained are physics learning outcomes of students who were learning with cooperative learning model in sub topic optic geometry inclass $X$ SMA Negeri 2 Lintongnihuta Academic Year 2014/2015 before being given treatment pre-test average of 48.65 and after being giventreatment posttest average for students 66.53. And so are the students learning out comes who were learning physics with conventional model in sub topic optic geometry class X SMA Negeri 2 Lintongnihuta Academic Year 2014/2015 before being given treatment pre-test average of 48.67 and after being given treatment the average post-test for students 48.67. There are differences instudent learning outcomes using the cooperative learning model of NHT type and to conventional model insub topic optic geometry inclass X SMA Negeri 2 Lintongnihuta.

Based on the research result and conclusions above, then as a follow-up of this study suggested some of the following expected for prospective teachers / researchers further repair activity descriptor in order to achieve the indicator as expected.The researchers further recommended to draw up indicators in observation activities in accordance with the syntax of methods / learning model used.Set time as efficiently as possible in the learning process so that each stage of learning can be done well.

\section{REFFERENCE}

Arends. R. I, 2009. Learning to Teach. New York: Me-Grraw-Hill

Arikunto,S,2011. Dasar-dasar Evaluasi Pendidikan. Jakarta : Bumi Aksara

Lie,2010. Cooperative Learning. Jakarta: PT.Gramedia 
Marbun,Lucius,2013. Skripsi Effect Cooperative Learning Model Type Number Head Together (NHT) OnStudent Learning Achievement on Expanction topic in grade VII semester I Junior High School State One A.Y. 2012/2013. Medan : UNIMED

Munir,2008. Kurikulum Berbasis TIK, Jakarta: PT.Grasindo

Sudjana,N,2008. Metode Statistika.

Bandung: tarsito

Trianto., 2009.Mendesain Model Pembelajaran InovatifProgresif, Jakarta : Kencana 